\title{
The role of service empathy and assurance in building customer loyalty in the Nigerian road transport industry
}

\author{
Madumere Humphrey Ikenna ${ }^{\mathrm{a}, *}$, Cletus I Emeti ${ }^{\mathrm{b}}$, Agu Godswill Agu ${ }^{\mathrm{c}}, \&$ Nwaizugbo Ireneus \\ Chukwudi $^{\mathrm{d}}$
}

\author{
${ }^{a}$ Department of Marketing, Nnamdi Azikiwe University, Awka, Nigeria \\ ${ }^{b}$ Department of Office and Information Management, Niger Delta University, Nigeria \\ ${ }^{c}$ Department of Marketing, Abia State University, Uturu, Nigeria \\ ${ }^{d}$ Department of Marketing, Nnamdi Azikiwe University, Awka, Nigeria
}

\begin{abstract}
Basing on the RATER model of service quality, we explored the role service empathy and assurance on road transport customers' loyalty intention. Being a quantitative study, data from 318 valid responses, analyzed with simple regression analysis in SPSS 21.0, indicate that the two constructs - service empathy and service assurance are positive and significant predictors of customer loyalty. Further, with $82 \%$ and $78.8 \%$ variance explained for assurance and empathy respectively, results indicate that service assurance drives more customer loyalty than service empathy in the organized road transport industry in Nigeria. To attract and retain customers, operators in the industry must be service quality conscious.
\end{abstract}

Keywords: Service Quality, RATER, Organized Road Transport Industry, Nigeria.

\section{Introduction}

Understanding, measuring and maintaining good service quality that can drive strong customer loyalty has remained a problem to many service providers. This is largely owing to the unique characteristics of service provision, which make service failure and customer dissatisfaction recurring issues in the service sector. This scenario is worst in the Nigerian Road Transport Sector, where road transport infrastructure, organizational policies and attitudes of staff result in perceived poor service quality and leading to unsteady customer loyalty. Researchers have revealed that what looks like customer loyalty in most organized road transport firms is not a function of high service quality delivery and performance but of other factors. Thus, Agu et al. (2018) as well as Agu and Okpara (2015] noted that it is due to factors such as nearness of terminals to customers' point of takeoff or destination, cost and unavailability of alternative transport service providers and difficulty in finding an operator that is really service quality conscious. This means that the key dimensions of service quality perception by customers have little or no contribution in the present loyalty displayed by road transport customers.

Explaining the meaning of service quality, authorities in marketing noted that it only varies in wording but typically involves determining whether perceived service delivery meets, exceeds or fails to meet customer expectations (Cronin \& Taylor, 1992). Supporting this argument, Czepiel (1990) asserts that service quality is a customer's perception of how well a service meets or exceeds their expectations. This implies that a customers' perception of a service affects their judgment of the quality level of the received service. To be perceived in a positive light, transport operators are required to steadily monitor customers' perception of their services.

\footnotetext{
* Corresponding author.

E-mail address: madumerehumphreyikenna@gmail.com (Madumere Humphrey Ikenna)
} 
Classifying the road transport operators into organized, semi-organized and open-market; roadside operators, Agu and Okpara (2015) observed that these levels of operators have customers who patronize them on a daily basis. The operators adopt various strategies to lure travelers (customers). Roslana et al. (2014) noted that the success of a road transport firm depends much on its ability to identify customers' wants and needs, and to come up with quality services that would meet their needs and keep them satisfied. Nkencho (2016) suggests that service providers such as the road transport operators should not just aim at meeting the expectations of the customers but to exceed these expectations and assure continuous high service quality provision more than other competitors. This will not only drive customer loyalty, but ensures that the benefits of customer loyalty (repeat patronage, positive word-of-mouth, recommendations, improved marketing performance) are attained (Agu \& Okpara, 2015; Ogwo \& Agu, 2015).

Although one may forcefully think that Nigerian road transport customers are largely economic conscious in their choices of road transport firms, to some class of road transporters, service quality perceptions play major role in determining patronage than economic considerations. For the organized road transport companies in Nigeria, much unlike their road-side, unorganized counterparts, the quality of service rendered, more than any other factor has much impact on patronage and loyalty (Agu \& Okpara, 2015). This is because, though a wide measure of difference exists in their respective fares, the organized transport firms still have very large share of the total market.

Understanding whether a relationship exists between service quality perception and customer loyalty is inevitable in the present road transport industry in Nigeria. However, given the intense competition in the industry, there is a greater need to understand customers' perceptions of the various organized road transport companies and their loyalty intentions in a comparative manner. This will help the management of these firms to know their ranks from the customers' viewpoint and to observe at a glance their key areas of strength and weaknesses in order to act appropriately.

Substantial studies abound in the areas of service quality and customer loyalty (Adeola \& Adebiyi, 2014; Jahanzeb et al., 2014; Saravanakumar \& Jayakrishnan, 2014) and transport management (Agu et al., 2018; Agu \& Okpara, 2015; Ogwo \& Agu, 2015). However, very little attention has been paid to service quality and customer loyalty in the organized road transport industry in Nigeria. This study tended to fill the gap in literature by using the RATER model of service quality, focusing on assurance and empathy, to examine the loyalty of customers to organized road transport firms in the South East of Nigeria. The present study however, tried to unravel the perception of road transport customers towards the service quality of their chosen firms and to ascertain the nature of relationship existing between such perceptual dispositions and customer loyalty intention using two components of the RATER model. Specifically, the study aimed to:

a) Measure the extent of relationship between perceived service assurance and customer loyalty intention.

b) Ascertain whether significant, positive relationship exists between perceived service empathy and customer loyalty intention.

\section{Review of Related Literature and Development of Hypotheses}

\subsection{Concept of Service Quality}

As noted by Agu (2015), the intangible nature of services has made it difficult for customers to state precisely the quality level of services paid for. In general terms, the word quality is taken to mean good quality, although allowance must be made for bad quality. Service Quality (SQ) can be defined as an assessment of how well a delivered service conforms to client's expectations. Service business operators often assess the service quality provided to their customers in order to improve their service, to quickly identify problems, and to better assess client satisfaction. To Anyanwu (2008), quality statements can only be made when a customer has experienced two standards of comparative elements. Levies and Boom (1983) as quoted in Anyanwu (2008) defined service quality as a measure of how well the service delivered matches customer expectations. Anyanwu (2008) asserts that the salient point in services delivery is "conformity to customer expectations on a consistent basis". On the other hand, Agu (2015) sees customer expectations as the levels of satisfaction, which the service consumer envisages to obtain after the 
consumption or reception of the service paid for. Thus, variations do occur when evaluating and/or comparing service quality performance with customer expectations. This results in quality failure such as delayed departure in the road transport services. According to Etzel et al. (2001), services providers must understand two key attributes of service quality: (i) Quality is defined by the customer and not by the provider (producer), and (ii) Customers evaluate service quality by comparing their expectations to their perception of how the service is performed.

\subsection{The RATER Model of Service Quality}

Several models of service quality have been developed and applied by previous researchers in the field of marketing. However, the present study was anchored on the RATER model proposed by (Zeithaml et al, 1990). Kalu (2015)pointed out that the model highlights five areas that customers generally consider to be important when they use a service. These are reliability (R), assurance (A), tangibles (T), empathy (E) and responsiveness (R). This study however, considers two areas of the model including assurance and empathy.

\section{Service quality assurance}

This is the area of the model, which deals with the knowledge, skills, and credibility of staff; and their ability to use this expertise to inspire trust and confidence among the customers. Iddrisu et al. (2015) noted that it also includes competence, courtesy, credibility and security. According to Andaleeb \& Conway (2006) assurance may not be so important relative to other industries where the risk is higher and the outcome of using the service is uncertain. For instance, in the medical and healthcare industry, assurance is an important dimension that customers use as criteria in assessing a hospital or a surgeon for an operation. The trust and confidence may be represented in the personnel who connect the customer to the organization (Iddrisu et al., 2015). In the transport firm therefore, the customers look forward to experiencing commendable knowledge of the staff on the services they seek, expertise in services rendering and credibility in handling modern technology in the process of service delivery. Any experience below this expectation may result in dissatisfaction with its negative consequences.

\section{Service quality empathy}

Empathy in service quality deals with the relationship between employees and customers. Zeithaml et al. (2006) noted that empathy entails caring and provision of individualized attention to customers by personnel of the firm. This makes the customer feel exceptional and extraordinary. In an attempt to develop empathy, personnel of the firm should endeavour to know the names of their customers, their preference and needs and take steps to gratify them (Iddrisu et al., 2015; Kalu, 2015). In the transport firm therefore, regular customers feel exceptional when they feel recognized by the staff, and treated courteously and politely.

\subsection{The Concept of Customer Loyalty}

In the view of Boahene and Agyapong (2011), it is agreed upon that the growth and continued existence of companies depend on how steadfast (loyal) their customers are in almost all industries. As a conservative word, loyalty describes faithfulness and keen attachment to a state, a cause, or an individual. It has been used in a business context to describe a customer's willingness to continue patronizing a firm over the long term, preferably on an exclusive basis or recommending the firm's products to friends and associates (Agyei \& Kilika, 2013). Customer loyalty is defined as customer's repeated patronage over a certain period of time (Ladhari et al., 2011; Yi \& Jeon, 2003). To Loverlock \& Writz (2007), customer loyalty extends beyond behaviour and includes preference liking and future intentions. Further, Ouet et al. (2011) in Agu and Okpara (2015) define loyalty as a held commitment to re-buy or re-patronize a preferred product consistently in the future. We see customer loyalty to a transport company as the willingness of the customer to remain with a particular transport firm over a given period. In all, Gremler and Brown (1996) in Kheng et al. (2010), offers one definition of customer loyalty that is related to our purpose in this study - customer loyalty is the degree to which a customer exhibits repeat purchasing behavior from a service provider, possesses a positive attitudinal disposition toward the provider, and considers using only this provider when a need for this service exists. 


\subsection{Service quality and Customer Loyalty}

[23] studied the impact of service quality on customer loyalty among banks in Penang, Malaysia. The population frame is customers of various local banks in Penang Island.. There were a total of 238 responses received at the end of data collection process. The findings show that improvement in service quality can enhance customer loyalty. The service quality dimensions that play a significant role are reliability, empathy, and assurance. Also, Iddrisu et al. (2015) investigated the relationship between service quality and customer loyalty in the Cellular industry of Ghana. The research was conducted after the introduction of the Mobile Number Portability (MNP) system. Survey questionnaire was used to collect 311 data from mobile users who are subscribers of 5 of the major cellular firms in Accra Metropolis of Ghana. The data were analyzed using correlation and multiple regression analysis. The findings revealed that service quality variables such as tangibles, responsiveness, reliability, assurance and empathy have a positive influence on customer loyalty through customer satisfaction. The result further revealed customer satisfaction has a direct relationship with customer loyalty.

Ivanauskienė \& Volungènaite (2014) investigated the relationship between service quality and customer loyalty across three emerging countries. The quantitative research data were collected through a survey of current customers of the specific retail sector, the household retail chain in Lithuania, Latvia and Estonia. Data obtained from 370 survey questionnaires were analyzed using SPSS Linear Regression statistical method. The study findings indicated that the dimensions of retail service quality in a specific sector of the industry are different in emerging markets compared to those that are in the original measurement scale such as RSQS. The study revealed that the three dimensions of service quality, namely, personal interaction (empathy), policy (assurance) and product quality have a positive impact on customer loyalty across household retail markets in the three researched countries. Leninkumar (2016) attempted to find the relationship between service quality dimensions and customer loyalty in the Commercial Banks of Sri Lanka. The data were collected from 30 customers of four leading commercial banks through questionnaires. The findings revealed that three dimensions of service quality namely tangibles, reliability and empathy have significant positive effect on customer loyalty. Further service quality dimensions alone explained 43.9\% of the variance in customer loyalty. The study by Bahadur et al. (2018) investigated the indirect effect of employee empathy (EE) on customer loyalty (CL) and loyalty outcomes through intervening variables, i.e. customer affective commitment, perceived service quality, and customer satisfaction (CS). Associations between the constructs of the proposed model were examined in the context of employee-customer interactions. Data were collected through the online survey from 360 useable responses collected from active users of telecommunication services from the province of Anhui, China. To test the model, structural equation modeling was applied by using AMOS 21. The findings confirmed the positive and indirect effect of EE on CL and loyalty outcomes (i.e. positive word-of-mouth and repurchase intentions).

Following the above discussions, we hypothesize that:

$\boldsymbol{H}_{1}$ : Service assurance relates positively with customer loyalty.

$\boldsymbol{H}_{2}$ : Service empathy relates positively with customer loyalty.

\section{Methods}

Given the nature of this study, the researcher adopted the survey research design. The study population consists of customers of the organized road transport firms operating in the South East. A purposive sample of 340 was assumed. Collected data were analyzed using descriptive and inferential statistics. Stated hypotheses were tested using Simple Regression Analysis at 0.05 level of significance and one-way Analysis of Variance (ANOVA) in SPSS version 21. The instrument was subjected to reliability and validity tests using Cronbach's alpha and experts' opinion respectively. Results confirm the reliability and validity of items. Extant scales were adopted from [Agu \& Okpara, 2015; Agyei \& Kilika, 2013; Kalu, 2015). 


\section{Result and Discussions}

\subsection{Data presentation and analyses}

The research instrument used in this study was structured questionnaire which was administered on randomly selected customers of the four organized road transport firms used for the study. The table below shows how the 318 copies of the questionnaire were distributed and retrieved.

Table 1. Distribution and Retrieval of Instrument

\begin{tabular}{cccccc}
\hline Transport Firms & ADPT & Copies Issued & $\begin{array}{c}\text { Copies Retrieved } \\
\text { and Used }\end{array}$ & Copies Lost & Percentage of Used \\
\hline A & 194 & 72 & 68 & 4 & 21.00 \\
B & 227 & 84 & 81 & 3 & 26.00 \\
C & 278 & 103 & 96 & 7 & 30.00 \\
D & 219 & 81 & 73 & 8 & 23 \\
\hline Total & $\mathbf{9 1 8}$ & $\mathbf{3 4 0}$ & $\mathbf{3 1 8}(\mathbf{9 4 \% )}$ & $\mathbf{2 2}(\mathbf{0 6 \%})$ & $\mathbf{1 0 0 . 0 0}$ \\
\hline
\end{tabular}

Source: Field survey, 2019.

Table 1 shows that the copies of questionnaire administered on customers of the road transport firms were based on the Average Daily Passenger Traffic (ADPT) of the firms as recorded in chapter three. Copies issued were ratios of the ADPT figures. A total of 340 copies were issued. 72, 84, 103 and 81 copies were issued to customers of A, B, C, and D, respectively. Of these figures, a total of 318 (94\%) copies were retrieved $-68(94 \%), 81(96 \%), 96(93 \%)$ and $73(90 \%)$ respectively for A, B, C, and D. Again, a total of 22 copies, representing 6\% were lost $-4(6 \%), 3(4 \%)$, $7(7 \%)$ and $8(10 \%)$ for A, B, C and D respectively. Thus, further analyses were based on the 318 copies retrieved and used.

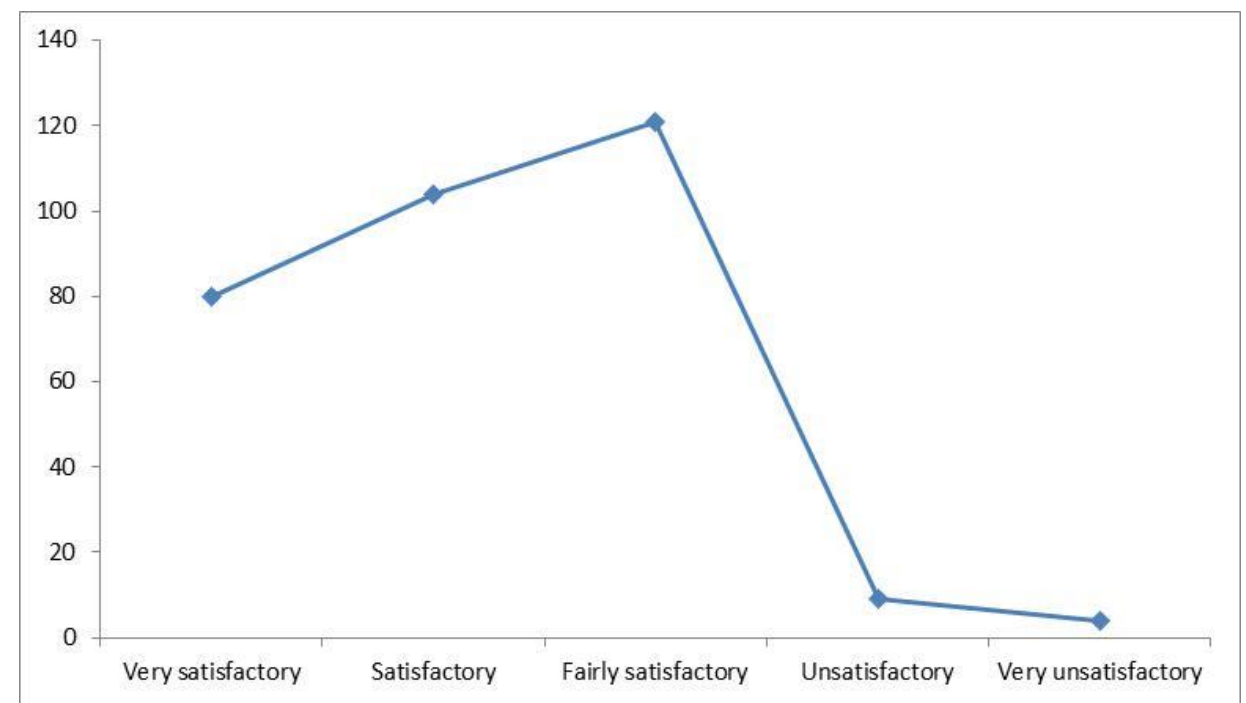

Fig. 1 Line graph showing respondents' rating of service quality 
Table 2. Responses to the rating of service quality

\begin{tabular}{lccc}
\hline & Options & Frequency & Percentage \\
\hline Very satisfactory & & 80 & 25.00 \\
Satisfactory & & 104 & 33.00 \\
Fairly satisfactory & & 121 & 38.00 \\
Unsatisfactory & & 9 & 03.00 \\
Very unsatisfactory & \multirow{2}{*}{ Total } & 4 & 01.00 \\
\hline & & $\mathbf{3 1 8}$ & $\mathbf{1 0 0 . 0 0}$ \\
\hline
\end{tabular}

Source: Field Survey, 2019

Table 2 and figure 1 show that 80(25\%), $104(33 \%), 121(38 \%), 9(3 \%)$, and 4(1\%) of the respondents disclosed that they were very satisfied, satisfied, fairly satisfied, unsatisfied and very unsatisfied with the service quality of the organized road transport companies.

Table 3. Analysis of responses to questions on customer loyalty

\begin{tabular}{|c|c|c|c|c|c|c|c|}
\hline $\mathbf{S N}$ & Statement & SA & $\mathbf{A}$ & $\mathbf{U N}$ & $\mathbf{D}$ & SD & Total \\
\hline 1. & I intend to re-patronize this company & 210 & 89 & 11 & 5 & 3 & 318 \\
\hline 2. & I will recommend its services to other customers. & 242 & 63 & 9 & 3 & 1 & 318 \\
\hline 3. & I will remain a loyal customer to this company. & 206 & 56 & 31 & 15 & 10 & 318 \\
\hline 4. & $\begin{array}{l}\text { I am ready to contribute in rebuilding the company } \\
\text { through suggestions to ensure that high service quality is } \\
\text { maintained. }\end{array}$ & 168 & 102 & 37 & 7 & 4 & 318 \\
\hline \multirow[t]{4}{*}{5.} & $\begin{array}{l}\text { In future, I expect to be rewarded in some sorts, as a long } \\
\text { time loyal customer. }\end{array}$ & 110 & 138 & 53 & 11 & 06 & 318 \\
\hline & Total & 936 & 448 & 141 & 41 & 24 & 1590 \\
\hline & Average & 187 & 90 & 28 & 8 & 5 & 318 \\
\hline & Percentage & 58 & 28 & 09 & 03 & 02 & 100 \\
\hline
\end{tabular}

\section{Source: Field Survey, 2020.}

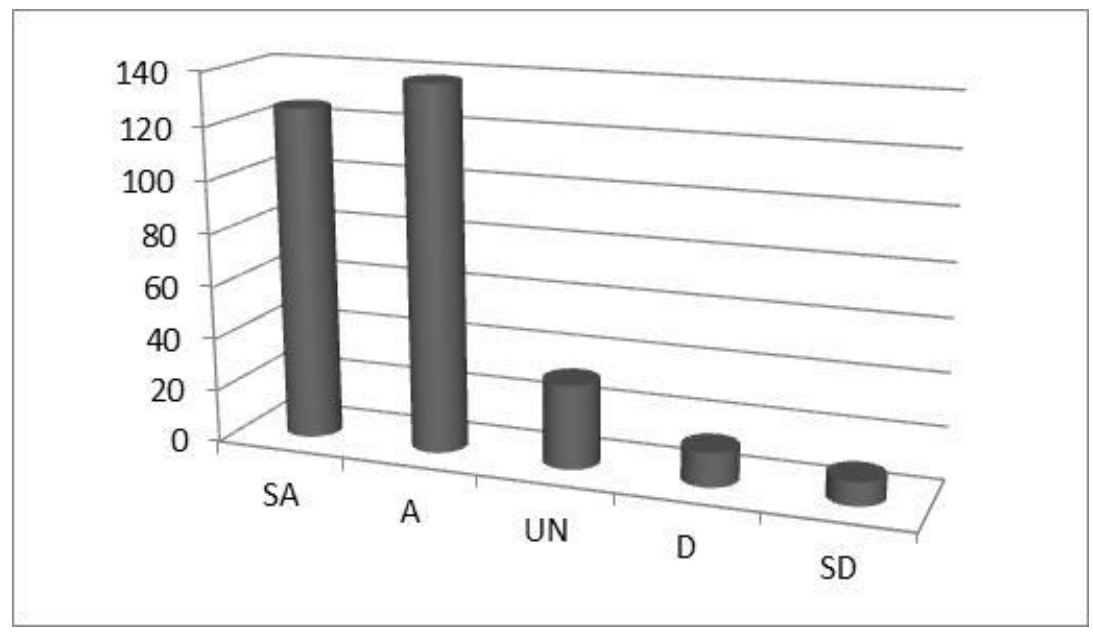

Fig. 2. Bar chart viewing responses to questions on customer loyalty 
Table 3 and figure 2 presented responses to the questions relating to customer loyalty. On the average, the table showed that $187(58 \%)$ respondents, $90(28 \%)$ respondents, $28(9 \%)$ respondents, $8(3 \%)$ respondents and $5(2 \%)$ respondents strongly agreed, agreed, were indifferent, disagreed and strongly disagreed respectively on the questions relating to customer loyalty.

Table 4. Analysis of responses on the effect of assurance on customer loyalty

\begin{tabular}{clcccccc}
\hline SN & \multicolumn{1}{c}{ Statement } & SA & A & UN & D & SD & Total \\
\hline 1. & Staff knowledge of required services is commendable. & 170 & 111 & 15 & 13 & 9 & $\mathbf{3 1 8}$ \\
2. & $\begin{array}{l}\text { Staff expertise in handling the service inspires confidence } \\
\text { in customers. }\end{array}$ & 128 & 95 & 58 & 20 & 17 & $\mathbf{3 1 8}$ \\
3. & $\begin{array}{l}\text { The credibility of staff in handling modern technology in } \\
\text { the sector is commendable. }\end{array}$ & 139 & 142 & 17 & 8 & 12 & $\mathbf{3 1 8}$ \\
\hline Total & $\mathbf{4 3 7}$ & $\mathbf{3 4 8}$ & $\mathbf{9 0}$ & $\mathbf{4 1}$ & $\mathbf{3 8}$ & $\mathbf{9 5 4}$ \\
& Average & $\mathbf{1 4 6}$ & $\mathbf{1 1 6}$ & $\mathbf{3 0}$ & $\mathbf{1 4}$ & $\mathbf{1 3}$ & $\mathbf{3 1 8}$ \\
& $\mathbf{4 6}$ & $\mathbf{3 6}$ & $\mathbf{1 0}$ & $\mathbf{0 4}$ & $\mathbf{0 4}$ & $\mathbf{1 0 0}$ \\
\hline
\end{tabular}

Source: Field Survey, 2020.

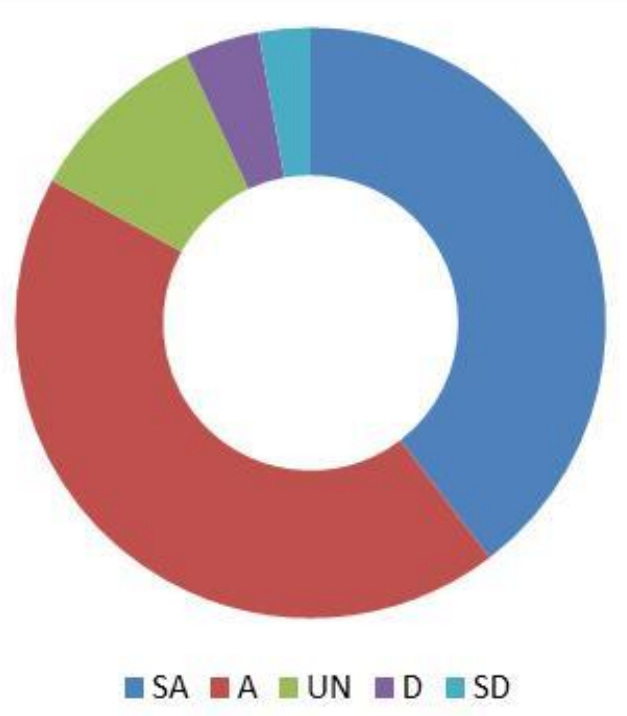

Fig. 3. Pie chart on responses on the effect of assurance on customer loyalty

Information presented in table 4 and figure 3 show that on the average, $146(46 \%)$ respondents, $116(36 \%)$ respondents, $30(10 \%)$ respondents, $14(4 \%)$ respondents and $13(4 \%)$ respondents strongly agreed, agreed, were indifferent, disagreed and strongly disagreed respectively on the questions relating to the effect of service quality assurance on customer loyalty. 
Table 5. Analysis of responses on the effect of empathy on customer loyalty

\begin{tabular}{clcccccc}
\hline SN & \multicolumn{1}{c}{ Statement } & SA & A & UN & D & SD & Total \\
\hline 1. & $\begin{array}{l}\text { A good number of the staff recognize and address me by } \\
\text { my name }\end{array}$ & 83 & 110 & 53 & 42 & 30 & $\mathbf{3 1 8}$ \\
2. & The staff of the firm is usually courteous and friendly. & 120 & 138 & 40 & 12 & 8 & $\mathbf{3 1 8}$ \\
3. & $\begin{array}{l}\text { The staff is quite polite and respectful in dealing with } \\
\text { customers. }\end{array}$ & 148 & 132 & 21 & 9 & 8 & $\mathbf{3 1 8}$ \\
\hline Total & $\mathbf{3 5 1}$ & $\mathbf{3 8 0}$ & $\mathbf{1 1 4}$ & $\mathbf{6 3}$ & $\mathbf{4 6}$ & $\mathbf{9 5 4}$ \\
& Average & $\mathbf{1 1 7}$ & $\mathbf{1 2 7}$ & $\mathbf{3 8}$ & $\mathbf{2 1}$ & $\mathbf{1 5}$ & $\mathbf{3 1 8}$ \\
Percentage & $\mathbf{3 7}$ & $\mathbf{3 9}$ & $\mathbf{1 2}$ & $\mathbf{0 7}$ & $\mathbf{0 5}$ & $\mathbf{1 0 0}$ \\
\hline
\end{tabular}

Source: Field Survey, 2020.

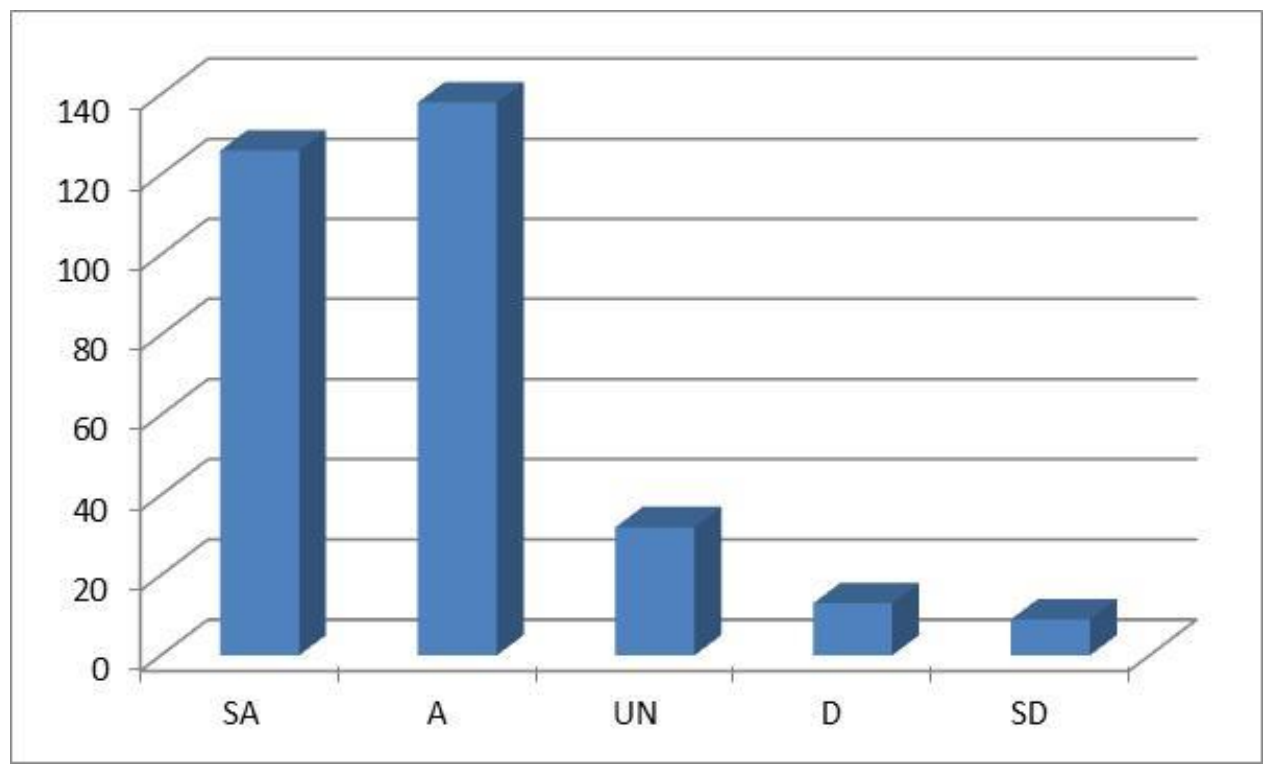

Fig. 4 Line graph on responses on the effect of empathy on customer loyalty

Data analyzed in table 5 and figure 4 showed an average of $117(37 \%)$ respondents, $127(39 \%)$ respondents, 38 (12\%) respondents, $21(7 \%)$ respondents and $15(5 \%)$ respondents who strongly agreed, agreed, were indifferent, disagreed and strongly disagreed respectively on the questions relating to the effect of service provider's empathy on customer loyalty.

\subsection{Test of Hypotheses}

Hypothesis one was tested using information contained on table 3. The SPSS output is presented below:

Model Summary ${ }^{\mathrm{b}}$

\begin{tabular}{|l|r|r|r|r|r|}
\hline Model & \multicolumn{1}{|c|}{$\mathrm{R}$} & $\mathrm{R}$ Square & $\begin{array}{c}\text { Adjusted R } \\
\text { Square }\end{array}$ & $\begin{array}{c}\text { Std. Error of the } \\
\text { Estimate }\end{array}$ & Durbin-Watson \\
\hline 1 & $0.912^{\mathrm{a}}$ & 0.832 & 0.831 & 0.35754 & 1.823 \\
\hline
\end{tabular}

a. Predictors: (Constant), Service Quality Assurance

b. Dependent Variable: Customer Loyalty 


\begin{tabular}{|rl|r|r|r|r|r|}
\hline Model & & Sum of Squares & \multicolumn{1}{|c|}{ df } & Mean Square & F & Sig. \\
\hline \multirow{3}{*}{1} & Regression & 200.081 & 1 & 200.081 & 156.51 & $0.000^{\mathrm{b}}$ \\
& Residual & 40.397 & 316 & 0.128 & & \\
& Total & 240.478 & 317 & & & \\
\hline
\end{tabular}

a. Dependent Variable: Customer Loyalty

b. Predictors: (Constant), Service Quality Assurance

Coefficients $^{\mathrm{a}}$

\begin{tabular}{|c|c|c|c|c|c|c|}
\hline \multirow{2}{*}{\multicolumn{2}{|c|}{ Model }} & \multicolumn{2}{|c|}{$\begin{array}{c}\text { Unstandardized } \\
\text { Coefficients }\end{array}$} & $\begin{array}{l}\text { Standardized } \\
\text { Coefficients }\end{array}$ & \multirow[t]{2}{*}{$\mathrm{T}$} & \multirow[t]{2}{*}{ Sig. } \\
\hline & & $\mathrm{B}$ & Std. Error & Beta & & \\
\hline \multirow{2}{*}{1} & (Constant) & 1.214 & 0.083 & & 14.618 & 0.000 \\
\hline & Service Quality Assurance & 0.767 & 0.019 & 0.912 & 39.562 & 0.000 \\
\hline
\end{tabular}

a. Dependent Variable: Customer Loyalty

Residuals Statistics ${ }^{\mathrm{a}}$

\begin{tabular}{|l|r|r|r|r|r|}
\hline & \multicolumn{1}{|c|}{ Minimum } & Maximum & \multicolumn{1}{c|}{ Mean } & Std. Deviation & \multicolumn{1}{c|}{ N } \\
\hline Predicted Value & 1.9810 & 5.0489 & 4.4025 & 0.79446 & 318 \\
Residual & -.98103 & 0.71808 & 0.00000 & 0.35698 & 318 \\
Std. Predicted Value & -3.048 & 0.814 & 0.000 & 1.000 & 318 \\
Std. Residual & -2.744 & 2.008 & 0.000 & 0.998 & 318 \\
\hline
\end{tabular}

a. Dependent Variable: Customer Loyalty

\section{Interpretation}

The $\mathrm{R}$ value in the model summary table shows a simple correlation of 0.912 which shows a strong and positive correlation. The $\mathrm{R}^{2}$ value shows how much of the total variation in the dependent variable (customer loyalty) that can be explained by the independent variable (service quality assurance). The table shows that $83.2 \%$ variation in customer loyalty to road transport firms can be explained by service quality assurance. This is very high. With a sig (p-value) of (0.000) which is less than Alpha (0.05), this implies that the overall regression model statistically predicts the outcome variable (That is, it is a good fit). This implies that service quality assurance is a significant predictor of customer loyalty among the respondents. Also, the Durbin Watson test shows that there is no first order autocorrelation since the value of DW produced by the SPSS is greater than the upper value (DU) from the critical table (1. 823) is greater than DU (1.820).

\section{Decision}

Since the P-value (0.000) is less than Alpha (0.05), that is $0.000<0.05$ and $\mathrm{F}$ cal (156.51) $>\mathrm{F}$ tab (3.84), we therefore validate the hypothesis, which implies that there is a significant, positive relationship between assurance and customer loyalty.

Hypothesis two was tested using information contained on table 4. The SPSS output is presented below:

\begin{tabular}{|c|c|c|c|c|c|}
\hline \multicolumn{6}{|c|}{ Model Summary } \\
\hline Model & $\bar{R}$ & R Square & $\begin{array}{l}\text { Adjusted R } \\
\text { Square }\end{array}$ & $\begin{array}{l}\text { Std. Error of the } \\
\text { Estimate }\end{array}$ & Durbin-Watson \\
\hline 1 & $0.888^{\mathrm{a}}$ & 0.788 & 0.788 & 0.40125 & 1.822 \\
\hline
\end{tabular}

a. Predictors: (Constant), Service Provider's Empathy

b. Dependent Variable: Customer Loyalty 
ANOVA $^{\mathrm{a}}$

\begin{tabular}{|rl|r|r|r|r|r|}
\hline Model & & Sum of Squares & df & Mean Square & F & Sig. \\
\hline \multirow{3}{*}{1} & Regression & 189.602 & 1 & 189.602 & 117.76 & $0.000^{\mathrm{b}}$ \\
& Residual & 50.876 & 316 & 0.161 & & \\
& Total & 240.478 & 317 & & & \\
\hline
\end{tabular}

a. Dependent Variable: Customer Loyalty

b. Predictors: (Constant), Service Provider's Empathy

Coefficients $^{\mathrm{a}}$

\begin{tabular}{|c|c|c|c|c|c|c|}
\hline \multirow{2}{*}{\multicolumn{2}{|c|}{ Model }} & \multicolumn{2}{|c|}{$\begin{array}{c}\text { Unstandardized } \\
\text { Coefficients }\end{array}$} & $\begin{array}{c}\text { Standardized } \\
\text { Coefficients } \\
\end{array}$ & \multirow[t]{2}{*}{$\mathrm{t}$} & \multirow[t]{2}{*}{ Sig. } \\
\hline & & B & $\begin{array}{l}\text { Std. } \\
\text { Error }\end{array}$ & Beta & & \\
\hline \multirow{2}{*}{1} & (Constant) & 1.572 & 0.086 & \multirow[b]{2}{*}{0.888} & 18.380 & 0.000 \\
\hline & Service Provider's Empathy & 0.712 & 0.021 & & 34.317 & 0.000 \\
\hline
\end{tabular}

a. Dependent Variable: Customer Loyalty

Residuals Statistics ${ }^{\text {a }}$

\begin{tabular}{|l|r|r|r|r|r|}
\hline & \multicolumn{1}{|c|}{ Minimum } & Maximum & \multicolumn{1}{c|}{ Mean } & \multicolumn{1}{c|}{ Std. Deviation } & \multicolumn{1}{c|}{ N } \\
\hline Predicted Value & 2.2838 & 5.1326 & 4.4025 & 0.77338 & 318 \\
Residual & -1.28383 & 0.71617 & 0.00000 & 0.40061 & 318 \\
Std. Predicted Value & -2.740 & 0.944 & 0.000 & 1.000 & 318 \\
Std. Residual & -3.200 & 1.785 & 0.000 & 0.998 & 318 \\
\hline
\end{tabular}

a. Dependent Variable: Customer Loyalty

\section{Interpretation}

The $\mathrm{R}$ value in the model summary table shows a simple correlation of 0.888 which shows a strong and positive correlation. The $\mathrm{R}^{2}$ value shows how much of the total variation in the dependent variable (customer loyalty) that can be explained by the independent variable (service provider empathy). The table shows that $78.8 \%$ variation in customer loyalty to road transport firms can be explained by service quality empathy. This is very high. With a sig ( $\mathrm{p}-$ value) of (0.000) which is less than Alpha (0.05), this implies that the overall regression model statistically predicts the outcome variable (That is, it is a good fit). This implies that service quality empathy is a significant predictor of customer loyalty among the respondents. Also, the Durbin Watson test shows that there is no first order autocorrelation since the value of DW produced by the SPSS is greater than the upper value (DU) from the critical table (1. 822) is greater than DU (1.820).

\section{Decision}

Since the P-value (0.000) is less than Alpha (0.05), that is $0.000<0.05$ and $\mathrm{F}$ cal (17.76) $>\mathrm{F}$ tab (3.84), we therefore validate the hypothesis, which implies that there is a significant, positive relationship between empathy and customer loyalty intention.

\subsection{Discussion of Findings}

This section critically discusses the findings of the study based on the results of the analyses of collected data, and paying attention to the empirical evidences of previous researchers as shown in the previous section. Studies on customer loyalty vary across countries and industries leading to varying outcomes in some instances. However, reviewed literature shows that empirical evidences support the fact that service quality, measured in the RATER model, has significant, positive impact on customer loyalty. That is, customer loyalty in terms of re-patronage, 
recommendation, retention, customer inputs (suggestions to help rebuild the firms) and loyalty rewards are attached greatly to the level of service quality offered by the road transport firms. This implies that the service quality level of the firms will influence the level of loyalty by the customers. $86 \%$ of the respondents positively affirmed this, thus leading to the key findings that service assurance and service empathy are positively and significantly related to customer loyalty in the organized road transport industry in Nigeria. The findings are in line with all the empirical works cited (see Bahadur, et al., 2018; Iddrisu et al., 2015; Ivanauskienė \& Volungènaitè, 2014; Kheng et al., 2010; Leninkumar, 2016).

\section{Conclusions}

In view of the lucrative nature of road transport entrepreneurship in Nigeria and the relatively high contribution of the segment to Gross Domestic Product from the transport sub-sector of the economy, a research on the service quality of operators is imperative. Given the intense competition within the industry, organized operators strive to maintain significant market share and customer loyalty by adopting different approaches. The service quality model (RATER) has been proven by marketing and management scholars as a reliable framework in service quality management. Made up of five critical variables (reliability, assurance, tangibles, empathy and responsiveness), the rater model explores contending areas of service relevance to customers. This study has been able to establish, though in alignment to many extant studies, that the rater variables (particularly assurance and empathy) are significant predictors of customer loyalty intention in South East Nigeria. Therefore, to constantly attract and retain customers, operators in the industry must be service quality conscious. When customers are satisfied with the service provision of operators, marketing performance indices will improve, leading to better competitive position. Just as previous scholars have recommended, the study encourages the organized road transporters to develop modern and customerfocused responsive mechanisms in tackling core areas of service failure within the firms, and which are key causes of customer defection. Such factors as poor staff attitude towards customers, delay in scheduled departure time, overloading, over speeding and use of poorly serviced vehicles should be carefully tackled as these have been proven to be prevalent in the unorganized road transport system, which these customers seek to avoid and are willing to pay more for a better service. There is also, the need to keep staff skill up-to-date in handling innovative areas in the road transport system. This builds a strong level of confidence and assurance that the service provider is capable of rendering the claimed services.

\section{References}

Adeola, M. M. \& Adebiyi, S. O. (2014). Service quality, perceived value and customer satisfaction as determinants of airline choice in Nigeria. International Letters of Social and Humanistic Sciences, 20(1), 66-80.

Agu, G. A. (2015). Customer complaint behaviour in the service industry: A study of the customers of the organized road transport firms in Imo State". A Ph.D. Thesis, Abia State University, Nigeria.

Agu, G.A., \& Okpara, G.S. (2015). Comparative complaint management strategies in the organized road transport firms in Imo State. Journal of Marketing Research, 4(1), 1-14.

Agu, G.A., Ogbuji, C.N., Okpara, G.S., \& Ogwo, E.O. (2008). Understanding customer complaint behavior for sustainable business development. Journal of Economics and Management Science, 1(3), 1-15.

Agyei, P. M. \& Kilika, J. M. (2013). The relationship between service quality and customer loyalty in the Kenyan mobile telecommunication service industry. European journal of Business and Management, 5(23), 26 - 36.

Andaleeb, S. S. \& Conway, C. (2006). Customer satisfaction in the restaurant industry: An examination of the transaction-specific model. Journal of Services Marketing, 20(1), 3-11.

Anyanwu, A. (2008). Service Recovery Strategies. In Nwokah, G N and Anyanwu, A (ed), Contemporary Book on Services Marketing. Avan Global Press. 
Bahadur, W., Aziz, S. \& Zulfiqar, S. (2018). Effect of employee empathy on customer satisfaction and loyalty during employee-customer interactions: The mediating role of customer affective commitment and perceived service quality. Cogent business \& management.

Boahene, R., \& Agyapong, G. K. Q. (2011). Analysis of the antecedents of customer loyalty of telecommunication industry in Ghana: The case of Vodafone (Ghana), International Business Research, 4 (1). Available at www.ccsenet.org/ibr

Cronin, J. J., Jr., \& Taylor, S. A. (1992). Measuring service quality: A reexamination and extension. Journal of Marketing, 56, 55-68.

Czepiel, J. A. (1990). Service encounters and service relationships: Implications for Research. Journal of Business Research, 20 (1), 13-21.

Etzel, M. J., Walker, B. J., \& Stanton, W, J. (2001). Marketing (12 ${ }^{\text {th }}$ ed.). Editora Makron Books Ltd.

Iddrisu, A. M., Nooni, I. K., Fianko, K. W. \& Mensa, W. (2015). Assessing the impact of service quality on customer loyalty: A study of the cellular industry in Ghana. British Journal of Marketing Studies 3(6), 15 - 30.

Ivanauskienè, N. \& Volungėnaité, J. (2014). Relations between service quality and customer loyalty: an empirical investigation of retail chain stores in emerging markets. American international journal of social science, $3(2), 113-120$.

Jahanzeb, S. Fatima, T. \& Khan, B. (2011). An empirical analysis of customer loyalty in pakistan's telecommunication industry. Journal of Database Marketing \& Customer Strategy Management (2011) 18, 5-15. doi:10.1057/dbm.2011.2

Kalu, I. N. (2015). Service quality and marketing performance of hotels in Abia and Imo State. Ph.D. Thesis: Department of Marketing, Abia State University, Uturu.

Kheng, L. L., Osman, M., Ramojah, T. \& Mosahab, R. (2010). The impact of service quality on customer loyalty: a study of banks in Penang Malaysia. International Journal of Marketing Studies 2(2).

Ladhari, R., Ladhari, I., \& Morales, M. (2011). Bank service quality: comparing Canadian and Tunisian customer perceptions. International Journal of Bank Marketing, 29 (3), 224 - 246

Leninkumar, V. (2016). The effect of service quality on customer loyalty. European Journal of Business Management, 8(33).

Loverlock, C., \& Writz, J. (2007). Services Marketing: People, Technology, Strategy, (6th ed.) Pearson Prentice Hall.

Nkencho, O. (2016). Services Marketing. In G.S.Okpara \& G.A. Agu (ed). Intermediate Marketing. Avan Global Press.

Ogwo, E. O., \& Agu, G. A. (2015). Transport infrastructure, manufacturing sector performance and growth of GDP in Nigeria, 1999 - 2014. Journal of Business and African Economy, 2(1),1-21.

Roslana,.A.A., Wahabb , E., \& Abdullah, H. ( 2014 )Service quality: A case study of logistics sector in Iskandar Malaysia using SERVQUAL model. Global Conference on Business \& Social Science-2014, GCBSS-2014, 15 th \& 16th December, Kuala Lumpur.

Saravanakumar, G. \& Jayakrishnan, J. (2014). Effect of service quality on customer loyalty: empirical evidence from co-operative bank. International Journal of Business and Administration Research Review, 2(4), JanMarch, 2014.

Yi, Y., \& Jeon, H. (2003). Effects of loyalty programme on value perception, Program loyalty and brand loyalty. Journal of the Academy of Marketing science, 31(3), 229- 240.

Zeithaml, Valarie A, A. Parasuraman \& Leonard L. Berry (1990). Delivering Quality Service: Balancing Customer Perceptions and Expectations: Free Press. 